\title{
Community acquired vs hospital acquired acute kidney injury. mortality and timing of renal replacement therapy
}

\author{
G Moreno-Gonzalez ${ }^{*}$ X Perez-Fernandez, P Cardenas-Campos, N Betancur-Zambrano, V Gumucio, D Toapanta, \\ S Contreras, V Corral-Velez, J Sabater, SIRAKI Group
}

From ESICM LIVES 2015

Berlin, Germany. 3-7 October 2015

\section{Objectives}

To analyse differences in survival between patients presenting community acquired advanced acute kidney injury (CAKIN3) and hospital acquired advanced acute kidney injury (HAKIN3). We also evaluated Renal Replacement Therapy (RRT) timing impact in these two populations.

\section{Methods}

We studied a cohort of 217 critically ill patients all of them presenting advanced acute kidney injury (AKIN3) at some point of their hospital stay. Patients with previous advanced chronic kidney disease (CKD5) were excluded. CAKIN3 was defined as those patients who presented AKIN3 at hospital admission and HAKIN3 was defined as those patients who presented no AKI at hospital admission. Both groups studied presented AKIN3 within the first 24h of ICU admission. To evaluate RRT timing impact we defined as Early RRT those patients whom were initiated on RRT within the first 48 hours from hospital admission (CAKIN3) or within the first 48 hours from ICU admission (HAKIN3). Patients with more than 7 days from hospital admission (CAKIN3) or ICU admission (KAKIN3) to RRT initiation were both excluded from RRT timing analysis. Non RRT control group was also included in timing analysis.

\section{Results}

90 days mortality was $51.5 \%$ in CAKIN3 patients and $71.1 \%$ in HAKIN3 patients $(\mathrm{p}=0.005)$. RRT was required in $82.8 \%$ of CAKIN3 patients vs $89.2 \%$ of HAKIN3 patients.
No differences between CAKIN3 and HAKIN3 were observed in terms of age (62 \pm 15 vs $61 \pm 14$ years), SOFA score $(12 \pm 4$ vs $12 \pm 4)$, baseline creatinine $(100 \pm 46$ vs $108 \pm 50 \mathrm{umol} / \mathrm{L})$, Lactate at ICU admission $(6.2 \pm 7 \mathrm{vs}$ $5.2 \pm 5.5 \mathrm{mmol} / \mathrm{L})$, days from ICU to RRT $(2.5 \pm 6.8 \mathrm{vs}$ $1.5 \pm 1.8$ days), urine output at RRT initiation ( $0.25 \pm 0.34$ vs $0.20 \pm 0.23 \mathrm{ml} / \mathrm{kg} / \mathrm{h}$ ), mechanical ventilation at RRT initiation ( $81 \%$ vs $79 \%)$, or presence of shock at RRT initiation $(94.6 \%$ vs $90.2 \%)$.

Differences between CAKIN3 and HAKIN3 were observed in terms of creatinine at hospital admission $(379 \pm 268$ vs $108 \pm 54 \mathrm{umol} / \mathrm{L})$, creatinine at ICU admission $(372 \pm 225 \mathrm{vs} 260 \pm 134 \mathrm{umol} / \mathrm{L})$, urine output within the first $24 \mathrm{~h}$ of ICU admission $(0.40 \pm 0.49$ vs $0.28 \pm 0.30 \mathrm{ml} / \mathrm{kg} / \mathrm{h}$ ), creatinine at RRT initiation $(435 \pm 205 \mathrm{vs} 337 \pm 128 \mathrm{umol} / \mathrm{L}), \mathrm{pH}$ at RRT initiation $(7.25 \pm 0.13$ vs $7.29 \pm 0.11)$, diabetes mellitus $(31.5 \%$ vs $19 \%$ ), and Chronic obstructive pulmonary disease-COPD $(23.1 \%$ vs $9.6 \%)$. Most of CAKIN3 patients were medical $(60.3 \%)$ and most of HAKIN3 patients were surgical (58.3\%).

In CAKIN3 patients Early RRT improved 90 day survival compared to Late RRT and non RRT patients ( $\mathrm{p}=$ 0.049). In HAKIN3 patients Early RRT had no survival impact compared to Late RRT or non-RRT patients.

\section{Conclusions}

Community acquired advanced AKI seems to present better outcome respect to hospital acquired advanced AKI. Early RRT seems to improve outcome in community acquired advanced AKI but has no beneficial impact on hospital acquired advanced AKI. 
Submit your manuscript to a SpringerOpen ${ }^{\circ}$ journal and benefit from:

- Convenient online submission

- Rigorous peer review

- Immediate publication on acceptance

- Open access: articles freely available online

- High visibility within the field

- Retaining the copyright to your article 